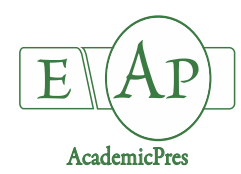

Dinca L et al. (2020)

Notulae Botanicae Horti Agrobotanici Cluj-Napoca 48(2):1070-1084

DOI: $10.15835 /$ nbha 48211824

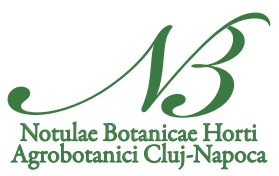

\title{
Productivity differences between southern and northern slopes of Southern Carpathians (Romania) for Norway spruce, silver fir, birch and black alder
}

\section{Lucian DINCĂ ${ }^{1}$, Gabriel MURARIU², Cristian Mihai ENESCU ${ }^{3}$, Florin ACHIM ${ }^{1}$, Lucian GEORGESCU ${ }^{2}$, Adrian MURARIU ${ }^{4}$, Voichița TIMIS,-GÂNSAC 5 , Liviu HOLONEC ${ }^{6 *}$}

\author{
1"Marin Drăcea" National Institute for Research and Development in Forestry, 128 Eroilor Bvdl., Voluntari, \\ Romania;dinka.lucian@gmail.com \\ 2"Dunărea de Jos" University of Galați, Faculty of Sciences and Environment, Chemistry, Physics and Environment Department, \\ 47 Domneasca Str., Galati, Romania; Gabriel.Murariu@ugal.ro \\ ${ }^{3}$ Department of Soil Sciences, University of Agronomic Sciences and Veterinary Medicine of Bucharest, 59 Marasti Blvd., Bucuresti, \\ Romania; mihaienescu21@gmail.com \\ ${ }^{4}$ Imperial College London, Physics Department, Prince Consort Rd, Kensington, London SW7 2BB, United Kingdom \\ ${ }^{5}$ University of Oradea, Faculty of Environmental Protection, 26 General Gheorghe Magheru Blvd., Oradea, Romania \\ ${ }^{6}$ University of Agricultural Sciences and Veterinary Medicine of Cluj-Napoca, Faculty of Horticulture, Department of Forestry, \\ 3-5 ManasturStr.,Cluj-Napoca,Romania; lholonec@usamvcluj.ro (*orresponding author)
}

\begin{abstract}
Forest vegetation across Southern Carpathians is distributed in altitudinal layers. The aim of this study was to highlight the productivity differences between the southern and northern slopes of the Southern Carpathians for Norway spruce, silver fir, birch and black alder. Data from 45 forest management plans ( 46.329 stands from the southern slopes and 32.787 stands from the northern slopes) were used. For each stand, the mean diameter, mean height, age, standing volume, current volume increment and production class were assessed. Elementary statistical methods were used to identify the factors influencing productivity. Significant differences between the southern and northern slopes were recorded for silver fir. The volume and the current volume increment were higher on the northern slopes. In the case of birch and black alder, the same two parameters recorded higher values on the southern slopes. As regards Norway spruce, insignificant differences were recorded between the two slopes. The correlation between structure type and stand volume was positive and statistically significant in the case of Norway spruce, silver fir and birch, but it was negative in the case of alder. Analysing the correlation between stand volume and the main stand characteristics also revealed a statistically significant positive correlation between age and stand volume for all analysed species. The results of this study are especially interested for the forest managers and forest owners whose aim is to obtain a higher productivity for the studied species.
\end{abstract}

Keywords: Abies alba; Alnus glutinosa; Betula pendula; Picea abies; volume increment 


\section{Introduction}

Carpathians account for a total area of $158.000 \mathrm{~km}^{2}$, of which $52.9 \%$ is distributed across Romania. Southern Carpathians, also called the Alps of Transylvania due to their similarities with the Alps in terms of relief (De Martonne, 1981), represent the highest Carpathians in Romania. Located in the south of the Transylvanian Depression, they are bordered on the east by Prahova Valley and on the west by Timiş-Cerna Corridor (Figure 1).

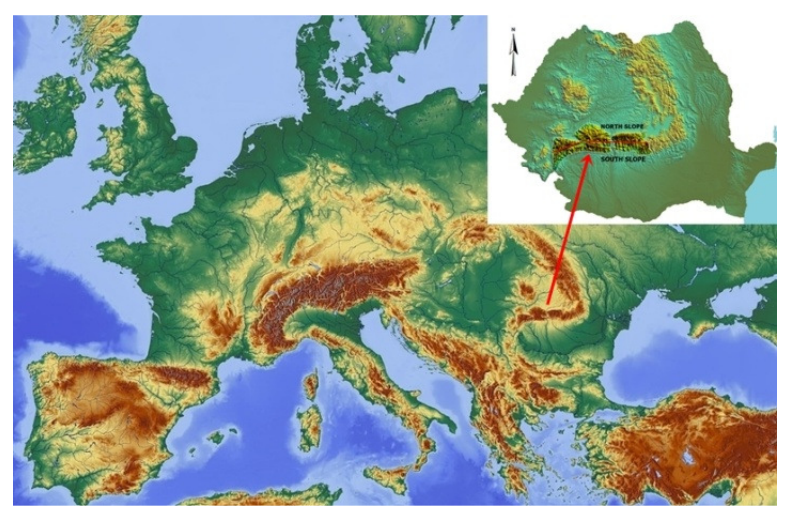

Figure 1. Southern Carpathians

This mountain range includes the highest peaks in Romania: Moldoveanu (2.544 $\mathrm{m}$ a.s.l.) and Negoiu (2.535 m a.s.1.), both situated in Făgăraș Mountains, and Parâng (2.519 m a.s.1.), Retezat (2.509 m a.s.1.) and Bucegi (2.505 $\mathrm{m}$ a.s.l.). The massif with the highest altitudes (i.e. Făgăraș) has the most important inherited glacial relief in the Southern Carpathians (Voiculescu, 2008).

Southern Carpathians are characterised by a temperate-mountain climate, ranging from a middlemountain climate (650-800 $\mathrm{m}$ a.s.l. towards $1850-1900 \mathrm{~m}$ a.s.l.) to a high-mountain climate (beyond 1850$1900 \mathrm{~m}$ a.s.l.). The mean air temperature ranges from $+7^{\circ} \mathrm{C}$ to $-2^{\circ} \mathrm{C}$ at altitudes of over $2100 \mathrm{~m}$ a.s.l. Rainfalls are influenced by the relief, with significant differences between the western and north-western slopes as well as between the eastern and south-eastern slopes. As such, rainfalls are heavier on the north-western slopes, recording average values of $800 \mathrm{~mm}$ /year on the southern border and approximately $1200 \mathrm{~mm}$ at higher elevations (Mihai et al., 2007).

The forest vegetation within this mountain range is distributed in altitudinal layers, starting with the deciduous forest layer, composed by common beech (Fagus sylvatica L.), hornbeam (Carpinus betulus L.), European white birch (Betula pendula L.), elm (Ulmus spp.), ash (Fraxinus spp.), and poplar (Populus spp.) and continuing with the mixed beech-coniferous species layer, the coniferous stands layer, composed by Norway spruce [Picea abies (L.) H. Karst] and silver fir (Abies alba Mill.), the subalpine layer, composed by common juniper (Juniperus communis L.) and bilberry (Vaccinium spp.) and the alpine layer (Grodzińska et al., 2004; Mihai et al., 2007). Based on the existing climate conditions, vegetation distribution and species dynamic, a number of vegetation belts were determined. As such, Southern Carpathians are characterised by deciduous species, mainly as a result of the warm climate. However, at the highest altitudes, coniferous forests are more predominant. Most of the Romanian Carpathians are characterised by the presence of deciduous forests, which are replaced by mixed and coniferous forests at higher altitudes (Grodzińska et al., 2004). Along the Southern Carpathians, several virgin forests were recently identified, some of which being the subject of research aimed at assessing the structural patterns and dynamics (Petrițan et al., 2017; Cântar et al., 2019).

In the past two decades, the health of forests across Southern Carpathians was good (Oneață et al., 2011; Badea et al., 2012). The productivity (increment) of forest stands in mountain areas, however, may be 
influenced by the climate (Grace et al., 2002; Lindner et al., 2010; Way, 2010), soil (Theurillat and Guisan, 2001; Spârchez et al., 2011; Lebourgeois et al., 2013; Moscatelli et al., 2017) or forest management (Mäkelä et al., 2000; Fürstenau et al., 2007; Liira et al., 2007; Bowes and Krutilla, 2014).

The studied area is characterised by, inter alia, a treeline shift into the alpine area (Dincă $e t$ al., 2017). Forest migration into the alpine area was reported in other regions across the globe (Gehring-Fasel et al., 2007; Hofgaard et al., 2013; Schickhoff et al., 2015).

In particular, beech forests across Iezer Mountains are considered to be the most dynamic. This conclusion results from the comparison with spruce forests $\left(6.3 \mathrm{~km}^{2}\right)$, mixed forests $\left(3.4 \mathrm{~km}^{2}\right)$ and wasteland areas and secondary meadows (together amounting to $3.6 \mathrm{~km}^{2}$ ). A similar situation has been encountered in mountain areas (Mihai et al., 2007), and it can be correlated with the natural regeneration of beech from deforested slopes.

In Parâng Mountains, the forests in the upper part are dominated by coniferous species, mainly Norway spruce and silver fir. At lower altitudes, mixed conifer-hardwood forests occur, the main species being the common beech, sycamore (Acer pseudoplatanus L.) and rowan (Sorbus aucuparia L.). Alders, mainly black alder [Alnus glutinosa (L.) Gaertn.] and grey alder [Alnus incana (L.) Moench.], and birches, especially European white birch are mainly distributed along the avalanche corridors, fixing the slopes with their roots (Pop et al., 2016).

In Retezat Mountains, the treeline is situated at approximately 1740 - $1800 \mathrm{~m}$ a.s.l. During the lateglacial period, the vegetation was mainly represented by the European larch (Larix decidua Mill.), mugo pine (Pinus mugo Turra) and Norway spruce (Magyari et al., 2012). Nowadays, the vegetation above this line is represented by alpine meadows and shrubs with mugo pine, extending up to $2200 \mathrm{~m}$ a.s.l. (Vespremeanu-Stroe et al., 2012). Coniferous forests do not exist in certain areas on the mountain's southern slopes, where they are replaced by mixed and deciduous forests. Sometimes these forests can even reach alpine meadows (Grodzińska et al., 2004). A number of dissimilarities between the northern and southern slopes can be observed in terms of the dynamics of treeline ecotones. The diverse lake elevations also cause an elevation of vegetation boundaries. Regardless of this aspect, between certain local events and the composition of species across the treeline ecotone several differences were noticed. For example, European larch is present in the area of Brazi Lake since the early Holocene stage, while silver fir is present on the northern slopes. As such, the local climate plays an essential role in the changes occurring in the area's treeline. Other local factors, however, also play an important role, especially in modulating local climatic patterns. Topography, moisture availability, microclimatic dissimilarities and the soil's capacity for retaining water are among the factors with the highest influence (Orbán, 2018; Oneț et al., 2019).

The aim of this study was to highlight the productivity differences between the southern and northern slopes of the Southern Carpathians (Romania) for Norway spruce, silver fir, European white birch and black alder, respectively.

\section{Materials and Methods}

\section{Field registration method}

Data from 45 forest management plans issued between 1980 and 2008 were used.

The mean diameter was measured for each stand, using a caliper, with a tolerance of $+/-10 \%$, as follows:

- in stands younger than 60 years old, for two to four trees for every two to three sampling plots;

- in even-aged stands over 60 years old, for three to five trees for every three to four sampling plots;

- in uneven-aged stands, for four to eight trees for every three to five sampling plots.

The mean height was measured for each stand for average trees, normally conformed, from the mean diameter category, with a tolerance of $+/-5 \%$. 
The age was determined for each stand, with a tolerance of $+/-10 \%$, by considering the data from the forest management plans or forest district regarding the year when the regeneration occurred and by adding the number of annual rings from the fresh stumps to the number of years required to achieve the height of the stem at which the determination was made. The age determined for each stand was rounded from 5 to 5 years for high-forest-regenerated stands and from 2 to 3 years for coppice-regenerated stands.

The standing volume was determined for each stand as follows:

- for stands that will be harvested in the first 10 years (stands with a difference of 10 years between the harvesting age and the current age), the volume was determined by statistical or integral inventories, with a tolerance of $+/-10 \%$ at a probability of $90 \%$;

- for the rest of the stands, the volume was determined by simplified procedures (by taking into account the simplified survey-based production tables), with a tolerance of $+/-12-15 \%$ at a probability of $80 \%$.

The current volume increment $\left(\mathrm{m}^{3} / \mathrm{year} / \mathrm{ha}\right)$ was determined for each stand by using the production tables and by considering the canopy cover, the current increment of the total production at the current age and the production class.

The production class was determined for each stand by means of height variation graphs in relation to the age or tables for the determination of the production classes.

Forest site conditions were described when forest planning works occurred, by conducting a mediumscale site study (1: 50.000). The determination of the forest site types was based on the soil studies and other factors that determine the characteristics of the respective forest sites, such as physical-geographic data, the rock type, the characteristics of flora and the natural forest type (Târziu et al., 2004; Spârchez et al., 2013).

Data from 46.329 stands from the southern side of the mountains, managed by 23 forest districts and occupying an area of 488.811 hectares, and 32.787 stands from the northern side of the mountains, managed by 23 forest districts and accounting for 317.960 hectares, were analysed.

In the case of Norway spruce, only pure stands (composition 100\% Norway spruce) were considered because this species forms pure stands and the goal was to eliminate the influence of other species on characteristics of interest. As regards the other three species, namely alder, birch and silver fir, all stands were considered, regardless of their composition, including the stands where these species were poorly represented, accounting for even less than $10 \%$ of the stand composition. Pure birch or silver fir stands are extremely rare.

\section{Data and statistical analysis}

The values were stratified by age (from 5 to 5 years, as the data are structured into the Romanian forest management plans) because the increments were differentiated according to this parameter.

The average values for volume $\left(\mathrm{m}^{3}\right)$, current volume increment $\left(\mathrm{m}^{3} / \mathrm{year} / \mathrm{ha}\right)$ and production class, differentiated between the two areas (north and south), were then calculated.

In order to determine the area occupied by each species, the area of the plot where each species appeared was multiplied by the percentage of participation of the species in the composition of the stand. For example, in a 10-ha forest stand with the composition $4 \mathrm{Mo} 4 \mathrm{Br} 2 \mathrm{Me}$, Norway spruce (ro. molid, abbrev. Mo) and silver fir (ro. brad, abbrev. Br) occupy 4 ha, while birch (ro. mesteacăn, abbrev. Me) occupies 2 ha.

The influence of the site factors (relief, terrain configuration, exposition, slope, altitude, soil type, flora, forest site type and type of forest) and the influence of the stand characteristics (age, structure, consistency) on the volume of the stand were also considered.

Afterwards, the data (tens of thousands of values) were centralized by using Microsoft Office Excel and the analyses were carried out by the aid of Tibco Statistica software package, version 13.3/2018. Pearson type correlation, stepwise regression and Multifactorial analysis of variance (MANOVA) were used in order to determine the relation between the volume of the stands, the studied variables and the two locations (northern and southern slopes) for the four species. 


\section{Results}

Areas occupied by various forest species in the Southern Carpathians

According to the data from the forest management plans issued around the year 2000, the total area of the forest across Southern Carpathians accounts for 806.771 ha (Table 1).

Table 1. Area occupied by main forest species across Southern Carpathians

\begin{tabular}{|c|c|c|c|c|c|c|}
\hline \multirow{2}{*}{ Species } & $\begin{array}{c}\text { Area of Southern Carpathians } \\
\text { on the Northern slope }\end{array}$ & $\begin{array}{c}\text { Area of Southern Carpathians } \\
\text { on the Southern slope }\end{array}$ & \multicolumn{2}{|c|}{$\begin{array}{c}\text { Total area of Southern } \\
\text { Carpathians }\end{array}$} \\
\cline { 2 - 7 } & Hectares & $\%$ & Hectares & $\%$ & Hectares & $\%$ \\
\hline Norway spruce & 131.412 & 41.3 & 159.522 & 32.6 & 290.934 & 36.1 \\
\hline Silver fir & 17.038 & 5.4 & 27.986 & 5.7 & 45.024 & 5.6 \\
\hline Birch & 6.206 & 2.0 & 12.815 & 2.6 & 19.021 & 2.3 \\
\hline Alder & 568 & 0.2 & 2.726 & 0.6 & 3.294 & 0.4 \\
\hline Hornbeam & 8.023 & 2.5 & 5.430 & 1.1 & 13.453 & 1.7 \\
\hline Beech & 120.196 & 37.8 & 236.613 & 48.4 & 356.809 & 44.2 \\
\hline Sessile oak & 13.853 & 4.4 & 14.503 & 3.0 & 28.356 & 3.5 \\
\hline European larch & 1.251 & 0.4 & 3.459 & 0.7 & 4.710 & 0.6 \\
\hline Sycamore maple & 1.682 & 0.5 & 1.424 & 0.3 & 3.106 & 0.4 \\
\hline Pine & 5.841 & 1.8 & 5.876 & 1.2 & 11.717 & 1.4 \\
\hline Others & 11.890 & 3.7 & 18.457 & 3.8 & 30.347 & 3.8 \\
\hline Total & 317.960 & & 488.811 & & 806.771 & \\
\hline
\end{tabular}

On the northern slopes of Southern Carpathians, as regards the percentages of participation in the composition of the forest stands, Norway spruce has a larger share, while the common beech has a lower one in comparison with the situation recorded on the southern slopes of these mountains. These two species occupy the largest area, accounting for $80 \%$ of the total area of Southern Carpathians, while the other species were less represented.

\section{Productivity differences between stands on the northern and southern sides of Southern Carpathians}

In the case of Norway spruce, 6.974 stands originating from the southern slopes and belonging to 23 forest districts and 5.032 stands originating from the northern slopes and managed by 23 forest districts were analysed. The average values for volume and production class are presented in Table 2 and the distribution of the mean values for current volume increment is given Figure 2.

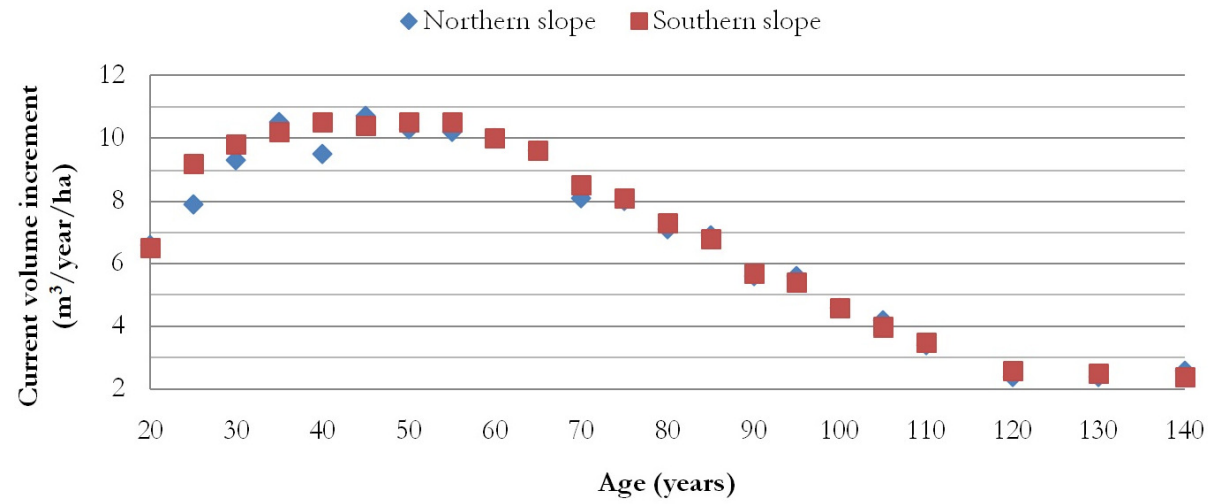

Figure 2. Productivity differences of Norway spruce stands between northern and southern slopes 
Table 2. Productivity differences of Norway spruce stands between northern and southern sides

\begin{tabular}{|c|c|c|c|c|}
\hline \multirow{2}{*}{$\begin{array}{c}\text { Age } \\
\text { (years })\end{array}$} & \multicolumn{2}{|c|}{ Volume $\left(\mathrm{m}^{3}\right)$} & \multicolumn{2}{c|}{ Production class } \\
\cline { 2 - 5 } & $\mathrm{N}$ & $\mathrm{S}$ & $\mathrm{N}$ & 3.39 \\
\hline 20 & 50 & 52 & 3.48 & 3.27 \\
\hline 25 & 73 & 97 & 3.39 & 3.29 \\
\hline 30 & 121 & 136 & 3.34 & 3.39 \\
\hline 35 & 171 & 165 & 3.44 & 3.31 \\
\hline 40 & 145 & 207 & 3.35 & 3.39 \\
\hline 45 & 241 & 235 & 3.41 & 3.35 \\
\hline 50 & 275 & 278 & 3.21 & 3.17 \\
\hline 55 & 321 & 333 & 3.14 & 3.10 \\
\hline 60 & 363 & 362 & 3.14 & 3.05 \\
\hline 65 & 393 & 378 & 3.35 & 3.04 \\
\hline 70 & 368 & 393 & 3.12 & 3.05 \\
\hline 75 & 407 & 405 & 3.33 & 3.31 \\
\hline 80 & 397 & 405 & 3.14 & 3.22 \\
\hline 85 & 446 & 431 & 3.54 & 3.57 \\
\hline 90 & 391 & 390 & 3.24 & 3.32 \\
\hline 95 & 462 & 429 & 3.56 & 3.58 \\
\hline 100 & 396 & 401 & 3.43 & 3.75 \\
\hline 105 & 411 & 374 & 3.78 & 3.87 \\
\hline 110 & 362 & 373 & 3.94 & 4.05 \\
\hline 120 & 342 & 368 & 3.89 & 3.95 \\
\hline 130 & 361 & 374 & 3.91 \\
\hline 140 & 435 & 386 & & \\
\hline
\end{tabular}

In the case of Norway spruce, the differences between the northern and southern slopes were insignificant in terms of the set of values recorded for the volume $(t=-0.368874, d f=21, p=0.715915)$, the growth rate $(t=-1.68440, d f=21, p=0.106911)$ and the production class $(t=-0.492751, d f=21, p=$ $0.627301)$.

As regards silver fir, 9.498 stands originating from the southern slope and belonging to 23 forest districts and 6.664 stands originating from the northern slope and managed by 22 forest districts were analysed. The mean values for current volume increment and production class are presented in Table 3 and the distribution of the average values for volume is given Figure 3.

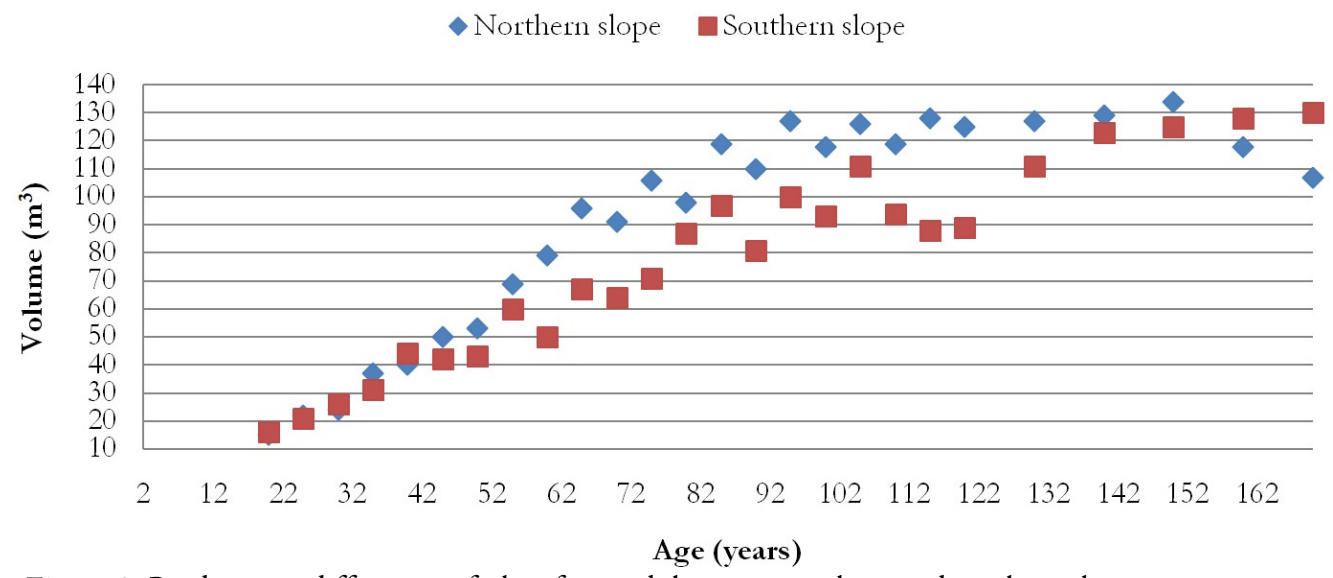

Figure 3. Productivity differences of silver fir stands between northern and southern slopes 
Table 3. Productivity differences of silver fir stands between northern and southern sides

\begin{tabular}{|c|c|c|c|c|}
\hline \multirow{2}{*}{$\begin{array}{c}\text { Age } \\
\text { (years) }\end{array}$} & \multicolumn{2}{|c|}{ Current volume increment $\left(\mathrm{m}^{3} /\right.$ year/ha) } & \multicolumn{2}{|c|}{ Production class } \\
\hline & $\mathrm{N}$ & (years) & $\mathrm{N}$ & $S$ \\
\hline 20 & 0.86 & 0.79 & 2.82 & 2.96 \\
\hline 25 & 1.49 & 1.32 & 2.79 & 2.89 \\
\hline 30 & 1.66 & 1.57 & 2.71 & 2.91 \\
\hline 35 & 2.41 & 1.80 & 2.68 & 2.90 \\
\hline 40 & 2.21 & 2.17 & 2.74 & 2.64 \\
\hline 45 & 2.30 & 1.95 & 2.54 & 2.95 \\
\hline 50 & 2.11 & 1.67 & 2.56 & 2.57 \\
\hline 55 & 2.35 & 2.57 & 2.64 & 2.17 \\
\hline 60 & 2.19 & 1.45 & 2.65 & 2.81 \\
\hline 65 & 2.55 & 1.8 & 2.44 & 2.91 \\
\hline 70 & 1.96 & 1.48 & 2.51 & 2.90 \\
\hline 75 & 2.07 & 1.42 & 2.35 & 2.56 \\
\hline 80 & 1.74 & 1.61 & 2.52 & 2.94 \\
\hline 85 & 1.91 & 1.64 & 2.23 & 2.73 \\
\hline 90 & 1.65 & 1.26 & 2.62 & 2.79 \\
\hline 95 & 1.70 & 1.65 & 2.37 & 2.58 \\
\hline 100 & 1.48 & 1.24 & 2.59 & 2.75 \\
\hline 105 & 1.42 & 1.35 & 2.38 & 2.79 \\
\hline 110 & 1.26 & 1.07 & 2.55 & 2.92 \\
\hline 115 & 1.22 & 0.89 & 2.23 & 2.88 \\
\hline 120 & 1.09 & 0.83 & 2.59 & 2.86 \\
\hline 130 & 1.08 & 1.02 & 2.62 & 2.85 \\
\hline 140 & 1.09 & 1.12 & 2.54 & 2.71 \\
\hline 150 & 1.06 & 1.03 & 2.64 & 2.68 \\
\hline 160 & 0.89 & 1.00 & 2.42 & 2.58 \\
\hline 170 & 0.70 & 1.00 & 2.79 & 2.46 \\
\hline
\end{tabular}

Significant differences between the two slopes were found. The volume $(t=4.716522, d f=25, p=$ $0.000078)$ and the current volume increment $(t=-4.092134, d f=25, p=0.000391)$ were higher on the northern side, while the production class recorded higher values on the southern slope $(t=-4.17415, d f=25$, $p=0.000316)$.

In the case of birch, 4.349 stands originating from the southern slope and belonging to 22 forest districts and 2.737 stands originating from the northern slope and managed by 20 forest districts were analysed. The values for volume $(t=-2.68868, d f=15, p=0.016837)$ and current volume increment $(t=-4.65340, d f=15$, $p=0.000312)$ were higher on the southern slope, while the values for production class $(t=-3.296975, d f=15$, $p=0.004889)$ were higher on the northern side. The differences in terms of current volume increment are given in Figure 4.

As regards black alder, 2.352 stands originating from the southern slope and belonging to 22 forest districts and 614 stands originating from the northern slope and managed by 16 forest districts were analysed.

In the case of alder, the statistical analysis revealed that the volume and the current volume increment were higher on the southern slope, while the production class was higher on the northern slope. Figure 5 highlights the differences as regards the volume recorded between the two slopes. 


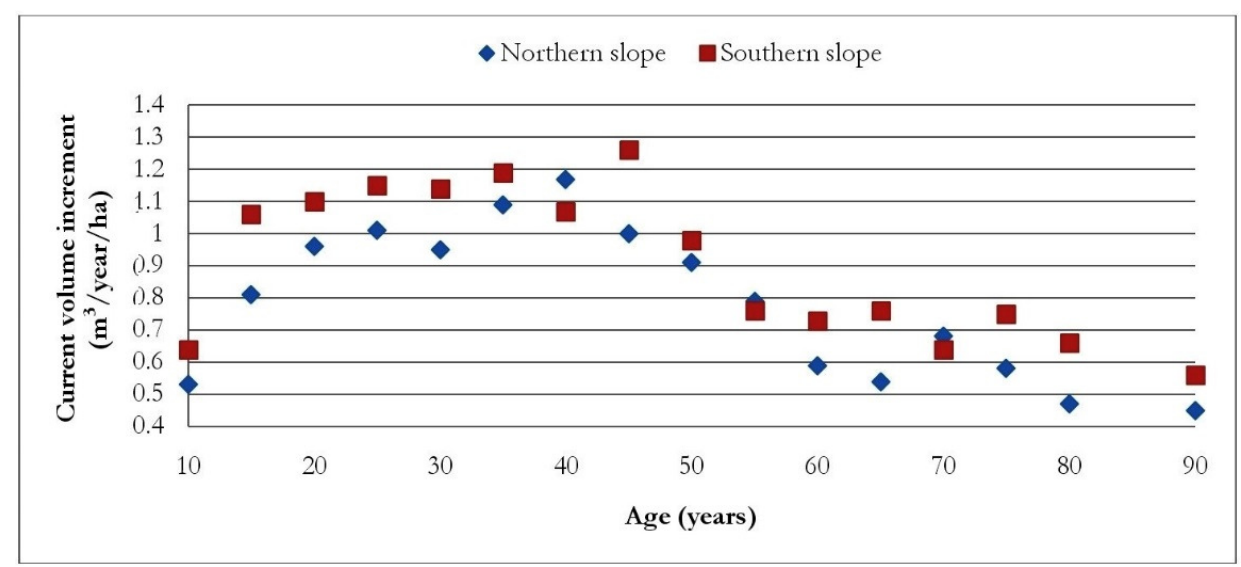

Figure 4. Productivity differences of birch stands between northern and southern slopes

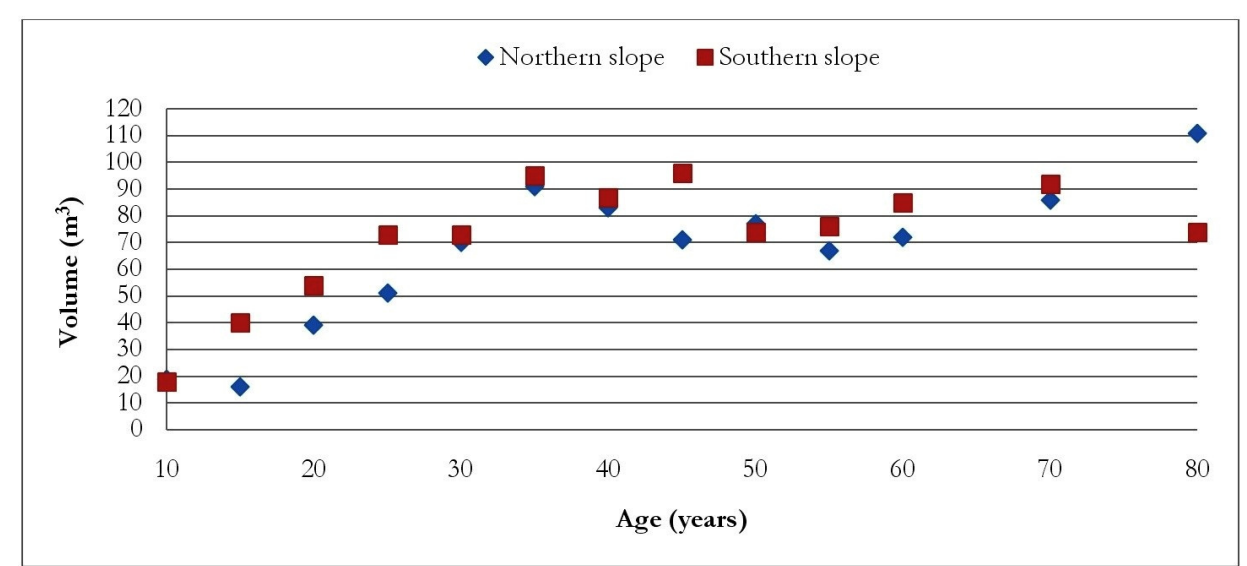

Figure 5. Productivity differences of alder stands between northern and southern slopes

\section{Factors that influence the increment of trees}

The influence of the forest site factors (relief-Rlf, configuration of the ground-Cnf, exposition-Exp, inclination of the ground-Inc, altitude-Alt, soil type-Sol, indicator flora-Flr, site type-ST, forest type-FT) and stand characteristics (age-Age, stand structure-Str, crown density-Cds) on the volume of the stand was studied.

Influence of the forest site factors and stand characteristics on the volume of the forest stands on the northern slopes

For all four species, the correlations between forest stand volume, the site and stand factors on the northern slope of Southern Carpathians are presented in Table 4 and the regression for silver fir in Table 5.

Analysing the correlation between forest stand volume and the main stand characteristics revealed a statistically significant positive correlation between age and stand volume for all analysed species. This correlation was strongest for Norway spruce and weakest for silver fir.

Furthermore, a positive forest type influence on stand volume was also observed. Soil type, meanwhile, had a negative correlation with stand volume in the case of Norway spruce and a positive correlation in the case of birch. The influence of exposition type and relief was statistically non-significant for most of the analysed species. 
Table 4. Correlations between the stand volume and the site and stand factors on the northern slope

\begin{tabular}{|c|c|c|c|c|c|c|c|c|c|c|c|c|}
\hline Species & Rlf & Cnf & $\operatorname{Exp}$ & Inc & Alt & Sol & Flr & ST & FT & Age & Str & Cds \\
\hline Mo & $\begin{array}{c}- \\
0.018 \\
\end{array}$ & $\begin{array}{c}- \\
0.139\end{array}$ & 0.012 & $\begin{array}{c}- \\
0.075 \\
\end{array}$ & $\begin{array}{c}- \\
0.221 \\
\end{array}$ & $\begin{array}{c}- \\
0.152 \\
\end{array}$ & 0.068 & 0.238 & 0.104 & 0.657 & 0.070 & 0.290 \\
\hline $\mathrm{p}$ & 0.177 & 0.00 & 0.296 & 0.477 & 0.00 & 0.00 & 0.026 & 0.00 & 0.002 & 0.00 & 0.00 & 0.00 \\
\hline $\mathrm{Br}$ & $\begin{array}{c}- \\
0.013 \\
\end{array}$ & $\begin{array}{c}- \\
0.555 \\
\end{array}$ & 0.165 & $\begin{array}{c}- \\
0.113 \\
\end{array}$ & $\begin{array}{c}- \\
0.144 \\
\end{array}$ & $\begin{array}{c}- \\
0.061 \\
\end{array}$ & $\begin{array}{c}- \\
0.009 \\
\end{array}$ & $\begin{array}{c}- \\
0.045 \\
\end{array}$ & $\begin{array}{c}- \\
0.069 \\
\end{array}$ & 0.383 & 0.32 & $\begin{array}{c}- \\
0.077 \\
\end{array}$ \\
\hline $\mathrm{p}$ & 0.315 & 0.00 & 0.215 & 0.00 & 0.00 & 0.00 & 0.493 & 0.00 & 0.00 & 0.00 & 0.00 & 0.00 \\
\hline $\mathrm{Me}$ & 0.058 & 0.003 & 0.017 & 0.022 & 0.005 & 0.056 & $\begin{array}{c}- \\
0.062 \\
\end{array}$ & 0.010 & $\begin{array}{c}- \\
0.015 \\
\end{array}$ & 0.498 & 0.190 & 0.001 \\
\hline $\mathrm{p}$ & 0.03 & 0.855 & 0.389 & 0.263 & 0.79 & 0.004 & 0.001 & 0.602 & 0.424 & 0.00 & 0.00 & 0.947 \\
\hline An & $\begin{array}{c}- \\
0.284 \\
\end{array}$ & $\begin{array}{c}- \\
0.238 \\
\end{array}$ & $\begin{array}{c}- \\
0.301 \\
\end{array}$ & $\begin{array}{c}- \\
0.347 \\
\end{array}$ & $\begin{array}{c}- \\
0.268 \\
\end{array}$ & 0.372 & 0.013 & 0.082 & 0.410 & 0.311 & $\begin{array}{c}- \\
0.045 \\
\end{array}$ & $\begin{array}{c}- \\
0.005 \\
\end{array}$ \\
\hline $\mathrm{p}$ & 0.00 & 0.00 & 0.00 & 0.00 & 0.00 & 0.00 & 0.748 & 0.049 & 0.00 & 0.00 & 0.281 & 0.902 \\
\hline
\end{tabular}

Table 5. Regression between stand volume, the site and stand factors on the northern slope for fir

\begin{tabular}{|c|c|c|c|c|c|c|}
\hline Factor & $\mathrm{b}^{*}$ & Std. Err. of $\mathrm{b}^{*}$ & $\mathrm{~b}$ & Std. Err. of b & $\mathrm{t}(9476)$ & $\mathrm{p}$-value \\
\hline Age & $\mathbf{0 . 6 9 2 8 6 6}$ & $\mathbf{0 . 0 1 2 0 6 1}$ & $\mathbf{1 . 1 2 8}$ & $\mathbf{0 . 0 1 9 6}$ & $\mathbf{5 7 . 4 4 8 5}$ & $\mathbf{0 . 0 0 0 0 0 0}$ \\
\hline Rlf & $\mathbf{0 . 0 2 8 0 7 9}$ & $\mathbf{0 . 0 0 8 4 6 5}$ & $\mathbf{1 . 6 5 8}$ & $\mathbf{0 . 4 9 9 7}$ & $\mathbf{3 . 3 1 7 1}$ & $\mathbf{0 . 0 0 0 9 1 3}$ \\
\hline Cnf & 0.009826 & 0.008872 & 2.160 & 1.9505 & 1.1075 & 0.268088 \\
\hline Exp & -0.005957 & 0.008662 & -0.077 & 0.1115 & -0.6877 & 0.491654 \\
\hline Inc & $\mathbf{- 0 . 1 9 1 3 1 8}$ & $\mathbf{0 . 0 0 9 2 3 8}$ & $\mathbf{- 1 . 8 5 7}$ & $\mathbf{0 . 0 8 9 7}$ & $\mathbf{- 2 0 . 7 0 9 7}$ & $\mathbf{0 . 0 0 0 0 0 0}$ \\
\hline Alt & $\mathbf{- 0 . 0 9 0 7 2 1}$ & $\mathbf{0 . 0 0 8 7 1 9}$ & $\mathbf{- 0 . 0 4 1}$ & $\mathbf{0 . 0 0 3 9}$ & $\mathbf{- 1 0 . 4 0 5 1}$ & $\mathbf{0 . 0 0 0 0 0 0}$ \\
\hline Sol & -0.011345 & 0.008802 & -0.001 & 0.0007 & -1.2888 & 0.197485 \\
\hline Flr & $\mathbf{- 0 . 0 2 3 5 4 7}$ & $\mathbf{0 . 0 0 8 7 3 2}$ & $\mathbf{- 0 . 4 2 7}$ & $\mathbf{0 . 1 5 8 4}$ & $\mathbf{- 2 . 6 9 6 8}$ & $\mathbf{0 . 0 0 7 0 1 4}$ \\
\hline ST & -0.016832 & 0.011106 & -0.004 & 0.0025 & -1.5156 & 0.129660 \\
\hline FT & $\mathbf{- 0 . 0 8 1 9 6 7}$ & $\mathbf{0 . 0 1 0 9 9 0}$ & $\mathbf{- 0 . 0 0 7}$ & $\mathbf{0 . 0 0 0 9}$ & $\mathbf{- 7 . 4 5 8 2}$ & $\mathbf{0 . 0 0 0 0 0 0}$ \\
\hline Str & $\mathbf{- 0 . 1 3 8 2 6 4}$ & $\mathbf{0 . 0 1 1 7 2 3}$ & $\mathbf{- 1 1 . 3 3 7}$ & $\mathbf{0 . 9 6 1 2}$ & $\mathbf{- 1 1 . 7 9 4 2}$ & $\mathbf{0 . 0 0 0 0 0 0}$ \\
\hline Cds & $\mathbf{0 . 1 6 2 2 9 1}$ & $\mathbf{0 . 0 0 9 2 5 8}$ & $\mathbf{1 0 3 . 3 4 6}$ & $\mathbf{5 . 8 9 5 4}$ & $\mathbf{1 7 . 5 2 9 8}$ & $\mathbf{0 . 0 0 0 0 0 0}$ \\
\hline
\end{tabular}

Abbreviations: Rlf-relief, Cnf-configuration of the ground, Exp-exposition, Inc-inclination of the ground, Alt-altitude,

Sol-soil type, Flr-indicator flora, ST-site type, FT-forest type, Age-age, Str-stand structure, Cds-crown density.

Influence of forest site factors and stand characteristics on the volume of the forest stands on the southern slope

For all four species, the correlations between the stand volume, site and stand factors on the southern slope of Southern Carpathians are given in Table 6 and the regression for Norway spruce in Table 7.

In the case of the southern slope of Southern Carpathians, it was observed that age and site type had a positive effect on stand volume. Structure type recorded a statistically significant positive correlation with stand volume for silver fir and birch and a negative correlation in the case of black alder. Relief type recorded a negative correlation for black alder and a positive correlation for silver fir and European white birch. From the perspective of altitude, the correlations were negative for all the analysed species. As altitude increased, stand volume decreased.

Influence of the forest site factors and stand characteristics on the volume of the forest stands across Southern Carpathians

The correlations between the stand volume, site and stand factors across Southern Carpathians are presented in Table 8. 
A statistically significant correlation between soil type and stand volume was observed in the case of black alder. Meanwhile, a negative correlation between soil type and stand volume was observed in the case of Norway spruce, silver fir and European white birch. In addition, inclination and forest type had a negative effect on stand volume. In the case of the southern slope of Southern Carpathians, it was observed that exposition and crown density had a positive effect on stand volume for black alder. Norway spruce, silver fir and European white birch did not record positive correlations between the stand volume and exposition. Ground configuration and flora indicator had a negative effect on stand volume for all studied species.

Table 6. Correlations between the stand volume, site and stand factors on the southern slope

\begin{tabular}{|c|c|c|c|c|c|c|c|c|c|c|c|c|}
\hline Species & Rlf & $\mathrm{Cnf}$ & Exp & Inc & Alt & Sol & Flr & ST & FT & Age & Str & $\mathrm{Cds}$ \\
\hline Mo & .002 & -.053 & .037 & .016 & -.060 & -.102 & .043 & .029 & .007 & .756 & .064 & .264 \\
\hline $\mathrm{p}$ & .842 & .000 & .002 & .169 & .000 & .000 & .000 & .015 & .516 & 0.00 & .000 & 0.00 \\
\hline $\mathrm{Br}$ & .024 & -.031 & .010 & -.156 & -.022 & -.062 & -.051 & -.109 & -.132 & .518 & .289 & -.052 \\
\hline $\mathrm{p}$ & .018 & .002 & .313 & 0.00 & .025 & 0.00 & 0.00 & 0.00 & 0.00 & 0.00 & 0.00 & 0.00 \\
\hline $\mathrm{Me}$ & .101 & .0107 & .0132 & -.004 & -.098 & .0205 & .036 & .108 & .111 & .511 & .152 & -.145 \\
\hline $\mathrm{p}$ & 0.00 & .048 & .385 & .756 & 0.00 & .176 & .015 & 0.00 & 0.00 & 0.00 & 0.00 & 0.00 \\
\hline An & -.305 & .0795 & -.324 & -.395 & -.267 & .166 & -.236 & .229 & .447 & .270 & -.232 & -.002 \\
\hline $\mathrm{p}$ & 0.00 & 0.00 & 0.00 & 0.00 & 0.00 & 0.00 & 0.00 & 0.00 & 0.00 & 0.00 & 0.00 & .917 \\
\hline
\end{tabular}

Table 7. Regression between the stand volume, site and stand factors on the southern slope for spruce

\begin{tabular}{|c|c|c|c|c|c|c|}
\hline Factor & $\mathrm{b}^{*}$ & Std. Err. of $\mathrm{b}^{*}$ & $\mathrm{~b}$ & Std. Err. of $\mathrm{b}$ & $\mathrm{t}(9476)$ & $\mathrm{p}$-value \\
\hline Age & $\mathbf{0 . 8 0 6 5 9 8}$ & $\mathbf{0 . 0 0 8 7 2 5}$ & $\mathbf{4 . 0 0 7 4}$ & $\mathbf{0 . 0 4 3 3}$ & $\mathbf{9 2 . 4 5 1 0}$ & $\mathbf{0 . 0 0 0 0 0 0}$ \\
\hline Rlf & $\mathbf{- 0 . 0 4 8 6 6 3}$ & $\mathbf{0 . 0 0 9 2 6 6}$ & $\mathbf{- 3 . 0 3 6 1}$ & $\mathbf{0 . 5 7 8 1}$ & $\mathbf{- 5 . 2 5 2 0}$ & $\mathbf{0 . 0 0 0 0 0 0}$ \\
\hline Cnf & $\mathbf{- 0 . 0 2 5 4 1 1}$ & $\mathbf{0 . 0 0 9 7 8 5}$ & $\mathbf{- 9 . 9 9 1 5}$ & $\mathbf{3 . 8 4 7 6}$ & $\mathbf{- 2 . 5 9 6 8}$ & $\mathbf{0 . 0 0 9 4 4 2}$ \\
\hline Exp & 0.001276 & 0.010374 & 0.0181 & 0.1474 & 0.1230 & 0.902114 \\
\hline Inc & $\mathbf{- 0 . 0 3 4 4 3 3}$ & $\mathbf{0 . 0 0 9 5 6 2}$ & $\mathbf{- 0 . 5 1 0 0}$ & $\mathbf{0 . 1 4 1 6}$ & $\mathbf{- 3 . 6 0 1 1}$ & $\mathbf{0 . 0 0 0 3 2 0}$ \\
\hline Alt & $\mathbf{- 0 . 1 6 7 7 7 4}$ & $\mathbf{0 . 0 1 3 0 0 5}$ & $\mathbf{- 0 . 1 2 1 7}$ & $\mathbf{0 . 0 0 9 4}$ & $\mathbf{- 1 2 . 9 0 1 1}$ & $\mathbf{0 . 0 0 0 0 0 0}$ \\
\hline Sol & $\mathbf{- 0 . 0 1 7 7 2 2}$ & $\mathbf{0 . 0 0 8 8 4 0}$ & $\mathbf{- 0 . 0 0 3 3}$ & $\mathbf{0 . 0 0 1 6}$ & $\mathbf{- 2 . 0 0 4 7}$ & $\mathbf{0 . 0 4 5 0 5 7}$ \\
\hline Flr & $\mathbf{- 0 . 0 4 7 4 1 5}$ & $\mathbf{0 . 0 1 2 1 3 0}$ & $\mathbf{- 1 . 0 9 3 0}$ & $\mathbf{0 . 2 7 9 6}$ & $\mathbf{- 3 . 9 0 9 0}$ & $\mathbf{0 . 0 0 0 0 9 4}$ \\
\hline ST & $\mathbf{0 . 1 7 1 2 4 3}$ & $\mathbf{0 . 0 1 5 2 9 8}$ & $\mathbf{0 . 0 3 8 9}$ & $\mathbf{0 . 0 0 3 5}$ & $\mathbf{1 1 . 1 9 3 8}$ & $\mathbf{0 . 0 0 0 0 0 0}$ \\
\hline FT & $\mathbf{- 0 . 0 5 4 3 7 9}$ & $\mathbf{0 . 0 1 3 0 8 1}$ & $\mathbf{- 0 . 0 1 0 7}$ & $\mathbf{0 . 0 0 2 6}$ & $\mathbf{- 4 . 1 5 7 0}$ & $\mathbf{0 . 0 0 0 0 3 3}$ \\
\hline Str & 0.005675 & 0.008777 & 1.8161 & 2.8087 & 0.6466 & 0.517933 \\
\hline Cds & $\mathbf{0 . 3 8 6 1 2 5}$ & $\mathbf{0 . 0 0 9 6 1 1}$ & $\mathbf{4 2 7 . 5 4 8 0}$ & $\mathbf{1 0 . 6 4 2 3}$ & $\mathbf{4 0 . 1 7 4 2}$ & $\mathbf{0 . 0 0 0 0 0 0}$ \\
\hline
\end{tabular}

Abbreviations: Rlf-relief, Cnf-configuration of the ground, Exp-exposition, Inc-inclination of the ground, Alt-altitude, Sol-soil type, Flr-indicator flora, ST-site type, FT-forest type, Age-age, Str-stand structure, Cds-crown density.

Table 8. Correlations between the stand volume, site and stand factors on the Southern Carpathians

\begin{tabular}{|c|c|c|c|c|c|c|c|c|c|c|c|c|}
\hline Species & Rlf & Cnf & Exp & Inc & Alt & Sol & Flr & ST & FT & Age & Str & Cds \\
\hline Mo & .034 & -.011 & .013 & -.053 & .160 & -.003 & -.201 & -.164 & -.167 & .469 & -.047 & .085 \\
\hline $\mathrm{p}$ & .000 & .005 & .002 & 0.00 & $\mathbf{0 . 0 0}$ & .440 & 0.00 & 0.00 & $\mathbf{0 . 0 0}$ & 0.00 & 0.00 & 0.00 \\
\hline $\mathrm{Br}$ & .007 & .004 & .025 & -.118 & -.050 & -.068 & -.061 & -.087 & -.109 & .479 & .214 & -.051 \\
\hline $\mathrm{P}$ & .318 & .572 & .001 & 0.00 & .000 & .000 & .000 & $\mathbf{0 . 0 0}$ & 0.00 & 0.00 & 0.00 & .000 \\
\hline $\mathrm{Me}$ & .135 & .002 & .039 & -.060 & -.067 & -.098 & .071 & .041 & .047 & .612 & .156 & -.090 \\
\hline $\mathrm{P}$ & .000 & .918 & .054 & .003 & .001 & .000 & .000 & .043 & .021 & 0.00 & .000 & .000 \\
\hline An & -.298 & -.055 & -.317 & -.371 & -.149 & .200 & -.192 & .201 & .421 & .265 & -.202 & .0119 \\
\hline $\mathrm{p}$ & 0.00 & .003 & 0.00 & 0.00 & .000 & 0.00 & 0.00 & 0.00 & 0.00 & 0.00 & 0.00 & .518 \\
\hline
\end{tabular}

Abbreviations: Rlf-relief, Cnf-configuration of the ground, Exp-exposition, Inc-inclination of the ground, Alt-altitude, Sol-soil type, Flr-indicator flora, ST-site type, FT-forest type, Age-age, Str-stand structure, Cds-crown density. 


\section{Discussion}

All four species are better represented on the southern slope than on the northern one. This phenomenon is explained by the fact that the northern area of Southern Carpathians is narrower (the slopes are steeper), while the mountains in the southern area have a lower inclination and a much longer length, allowing for a larger number of large trees stands. The larger distribution range of Norway spruce and the lower distribution of beech forests across the northern slopes as compared to the southern slopes are closely correlated with climatic characteristics that are more favourable to Norway spruce in the north and more favourable to common beech in the south (Wiser et al., 1997; Hertel and Schöling, 2011; Sharma et al., 2012).

According to Avery and Burkhart (2002), the site index describes the potential for forest trees to grow at a particular site. It is used to measure the productivity of the site and the management options for that site and reports the height of dominant and co-dominant trees in a stand at a base age. A lower value for site index (i.e. a higher stand quality) indicates higher volumes and growth, as it was the case of silver fir on the northern slopes and European white birch and black alder on the southern side, respectively.

In the case of silver fir, higher volumes and current volume increments were recorded on the northern slopes. This could be explained by the ecology of the species. Silver fir is a very shade-tolerant species (Toromani et al., 2011; Mauri et al., 2016) that is well adapted to lower temperatures (Pinto et al., 2008), frosts (Lebourgeois, 2007), and, in particular, higher levels of precipitation (Rolland et al., 1999). It was also reported that the highest temperatures recorded in August positively influence the growth of the silver fir (Lebourgeois, 2014).

In comparison with silver fir, European white birch and black alder, two pioneer species (Beck et al., 2016; Houston Durrant et al., 2016), prefer higher temperatures (Weih and Karlsson, 2001; Hesslerová et al., 2013) and they are adapted to a slightly lower level of humidity (Parts at al., 2013; Rosenvald et al., 2014). This is why their productivity is higher on the southern slopes of the studied mountain range. In the case of black alder, temperature is the climatic factor with the greatest influence on increment. The species grows mainly along the valleys of the rivers, where higher temperatures and sufficient humidity exist.

As regards Norway spruce, no differences between the northern and southern slopes were recorded, probably because this species has a great ecological amplitude (Williams and Liebhold, 2000; Pretzsch and Dursky, 2002), Picea abies being more resistant to drought and frost than silver fir, and its presence decreases with an increase in altitude (Lebourgeois, 2010; Lebourgeois, 2013). In an analysis of 40 stands along a transect of over $500 \mathrm{~km}$ ranging from central Finland to the Arctic spruce treeline, Makine et al. (2000) observed that the standard deviation of the ring-width series increased from south to north and that the most pronounced differences in the regional increment chronologies were found between the southernmost and northernmost stands.

\section{Conclusions}

Since four fifths of the total forested area of Southern Carpathians are represented by two species, namely Norway spruce and common beech, on one hand, and by taking into account the higher productivity recorded for silver fir on the northern side and the insignificant difference between the two slopes in the case of Norway spruce's productivity, on another hand, future forest planning measures should increase the share of silver fir in the mixed forests or even in pure Norway spruce forests across northern side of Southern Carpathians. Introducing silver fir in various shares in pure Norway spruce forests will increase their stability against windfalls.

As regards the influence of forest site factors and stand characteristics on stand volume, it was observed that altitude influenced stand volume, which decreased as altitude increased. The relief type did not correlate 
significantly with stand volume for Norway spruce but recorded negative values for black alder and positive values for silver fir and European white birch. It was observed that age and site type had a positive effect on stand volume on the southern slope of the Southern Carpathians. The correlation between structure type and stand volume was positive and statistically significant in the case of Norway spruce, silver fir and European white birch, but it was negative in the case of black alder. The relief type did not significantly correlate with volume in the case of Norway spruce but it recorded a negative correlation for black alder and a positive correlation for silver fir and European white birch. The correlations were negative for all analysed species from the perspective of altitude, with stand volume decreasing as altitude increased.

Analysing the correlation between stand volume and the main stand characteristics also revealed a statistically significant positive correlation between age and stand volume for all analysed species. This correlation was strongest for Norway spruce and weakest for silver fir.

In conclusion, this study provides important results regarding the productivity of four of the most common tree species across Southern Carpathians. These results are especially interested for the forest managers and forest owners whose targets consist in obtaining higher timber volumes, that means additional income obtained from selling the wood, as in the case of Norway spruce and silver fir. Moreover, as regards the species that are not valued from economic perspectives, such as European white birch and black alder, higher productivity means higher quantities of carbon stored that could be exploited on the international market.

\section{Acknowledgements}

This research received no specific grant from any funding agency in the public, commercial, or not-forprofit sectors.

\section{Conflict of Interests}

The authors declare that there are no conflicts of interest related to this article.

\section{References}

Avery TE, Burkhart HE (2002). Forest measurements. McGraw-Hill (5th ed), New York.

Badea O, Bytnerowicz A, Silaghi D, Neagu S, Barbu I, Iacoban C, ... Tăut I (2012). Status of the Southern Carpathian forests in the long-term ecological research network. Environmental Monitoring and Assessment 184(12):74917515.

Beck P, Caudullo G, de Rigo D, Tinner W (2016). Betula pendula, Betula pubescens and other birches in Europe: distribution, habitat, usage and threats. In: San-Miguel-Ayanz J, de Rigo D, Caudullo G, Houston Durrant, T, Mauri A (Eds.). European Atlas of Forest Tree Species. Publ. Off. EU, Luxembourg, pp e010226+.

Bowes MD, Krutilla JV (2014). Multiple-use management: the economics of public forestlands. Routledge.

Cântar IC, Dincă L, Chisăliță I, Crișan V, Kachova V (2019). Identifying the oldest stands from the Southern Carpathians together with their main characteristics. Proceedings of the Multidisciplinary Conference on Sustainable development. Filodiritto International Proceedings pp 186-193.

De Martonne E (1981). Cercetări asupra evoluției morfologice a Alpilor Transilvaniei (Carpaţii Meridionali) [Research regarding the evolution of Transylvanian Alps (Southern Carpathians)]. Editura Academiei Republicii Socialiste România, București.

Dincă L, Niţă MD, Hofgaard A, Alados CL, Broll G, Borz SA, ... Monteiro AT (2017). Forests dynamics in the montanealpine boundary: a comparative study using satellite imagery and climate data. Climate Research 73(1-2):97-110. 
Fürstenau C, Badeck FW, Lasch P, Lexer MJ, Lindner M, Mohr P, Suckow F (2007). Multiple-use forest management in consideration of climate change and the interests of stakeholder groups. European Journal of Forest Research 126(2):225-239.

Gehrig-Fasel J, Guisan A, Zimmermann NE (2007). Tree line shifts in the Swiss Alps: climate change or land abandonment? Journal of Vegetation Science 18(4):571-582.

Grace J, Berninger F, Nagy L (2002). Impacts of climate change on the tree line. Annals of Botany 90(4):537-544.

Grodzińska K, Godzik B, Frączek W, Badea O, Oszlányi J, Postelnicu D, Shparyk Y (2004). Vegetation of the selected forest stands and land use in the Carpathian Mountains. Environmental Pollution 130(1):17-32.

Hertel D, Schöling D (2011). Below-ground response of Norway spruce to climate conditions at Mt. Brocken (Germany)A re-assessment of Central Europe's northernmost treeline. Flora-Morphology, Distribution, Functional Ecology of Plants 206(2):127-135.

Hesslerová P, Pokorný J, Brom J, Rejšková-Procházková A (2013). Daily dynamics of radiation surface temperature of different land cover types in a temperate cultural landscape: Consequences for the local climate. Ecological engineering 54:145-154.

Hofgaard A, Tømmervik H, Rees G, Hanssen F (2013). Latitudinal forest advance in northernmost Norway since the early 20th century. Journal of Biogeography 40(5):938-949.

Houston Durrant T, de Rigo D, Caudullo G (2016). Alnus glutinosa in Europe: distribution, habitat, usage and threats. In: San-Miguel-Ayanz J, de Rigo D, Caudullo G, Houston Durrant T, Mauri A (Eds.). European Atlas of Forest Tree Species. Publ. Off. EU, Luxembourg, pp e01f3c0+.

Hu S, Ma J, Shugart HH, Yan X (2018). Evaluating the impacts of slope aspect on forest dynamic succession in Northwest China based on FAREAST model. Environmental Research Letters 13(3):034027.

Lebourgeois $\mathrm{F}$ (2007). Climatic signal in annual growth variation of silver fir (Abies alba Mill.) and spruce (Picea abies Karst.) from the French Permanent Plot Network (RENECOFOR). Annals of Forest Science 64:333-343.

Lebourgeois F, Rathgeber CB, Ulrich E (2010). Sensitivity of French temperate coniferous forests to climate variability and extreme events (Abies alba, Picea abies and Pinus sylvestris). Journal of Vegetation Science 21(2):364-376.

Lebourgeois F, Gomez N, Pinto P, Mérian P (2013). Mixed stands reduce Abies alba tree-ring sensitivity to summer drought in the Vosges mountains, western Europe. Forest Ecology and Management 303:61-71.

Lebourgeois F, Eberle P, Mérian P, Seynave I (2014). Social status-mediated tree-ring responses to climate of Abies alba and Fagus sylvatica shift in importance with increasing stand basal area. Forest Ecology and Management 328:209-218.

Lindner M, Maroschek M, Netherer S, Kremer A, Barbati A, Garcia-Gonzalo J, ... Marchetti M (2010). Climate change impacts, adaptive capacity, and vulnerability of European forest ecosystems. Forest Ecology and Management 259(4):698-709.

Liira J, Sepp T, Parrest O (2007). The forest structure and ecosystem quality in conditions of anthropogenic disturbance along productivity gradient. Forest Ecology and Management 250(1-2):34-46.

Magyari EK, Jakab G, Bálint M, Kern Z, Buczkó K, Braun M (2012). Rapid vegetation response to late glacial and early Holocene climatic fluctuation in the South Carpathian Mountains (Romania). Quaternary Science Reviews 35:116-130.

Mäkelä A, Landsberg J, Ek AR, Burk TE, Ter-Mikaelian M, Ågren GI, Puttonen P (2000). Process-based models for forest ecosystem management: current state of the art and challenges for practical implementation. Tree physiology 20(5-6):289-298.

Mäkinen H, Nöjd P, Mielikäinen K (2000). Climatic signal in annual growth variation of Norway spruce (Picea abies) along a transect from central Finland to the Arctic timberline. Canadian Journal of Forest Research 30(5):769777.

Mauri A, de Rigo D, Caudullo G (2016). Abies alba in Europe: distribution, habitat, usage and threats. In: San-MiguelAyanz J, de Rigo D, Caudullo G, Houston Durrant T, Mauri A (Eds). European Atlas of Forest Tree Species. Publ. Off. EU, Luxembourg, pp e01493b+.

Mihai B, Săvulescu I, Sandric I (2007). Change detection analysis (1986-2002) of vegetation cover in Romania: a study of alpine, subalpine, and forest landscapes in the Iezer Mountains, Southern Carpathians. Mountain Research and Development 27(3):250-258.

Moscatelli MC, Bonifacio E, Chiti T, Cudlín P, Dincă L, Gömöryova E, ... Broll G (2017). Soil properties as indicators of treeline dynamics in relation to anthropogenic pressure and climate change. Climate Research 73(1-2):73-84. 
Oneață M, Dincă L, Ciuvăț L, Ionescu M (2011). Analiza nivelului de nutrienți în circuitul frunze-litieră-sol din rețeaua de monitoring intensiv. Revista Pădurilor 126(3-4):35-47.

Oneț A, Dincă LC, Grenni P, Laslo V, Teusdea AC, Vasile DL, ... Crișan VE (2019). Biological indicators for evaluating soil quality improvement in a soil degraded by erosion processes. Journal of Soils and Sediments 19(5):23932404.

Orbán I, Birks HH, Vincze I, Finsinger W, Pál I, Marinova E, ... Magyari EK (2018). Treeline and timberline dynamics on the northern and southern slopes of the Retezat Mountains (Romania) during the late glacial and the Holocene. Quaternary International 477:59-78.

Parts K, Tedersoo L, Lõhmus K, Kupper P, Rosenvald K, Sõber A, Ostonen I (2013). Increased air humidity and understory composition shape short root traits and the colonizing ectomycorrhizal fungal community in silver birch stands. Forest Ecology and Management 310:720-728.

Pinto PE, Gégout JC, Hervé JC, Dhôte JF (2008). Respective importance of ecological conditions and stand composition on Abies alba Mill. dominant height growth. Forest Ecology and Management 255(3-4):619-629.

Petrițan IC, Commarmot B, Hobi ML, Petrițan AM, Bigler C, Abrudan IV, Rigling A (2015). Structural patterns of beech and silver fir suggest stability and resilience of the virgin forest Sinca in the Southern Carpathians, Romania. Forest Ecology and Management 356:184-195.

Pop OT, Gavrilă IG, Roşian G, Meseşan F, Decaulne A, Holobâcă IH, Anghel T (2016). A century-long snow avalanche chronology reconstructed from tree-rings in Parâng Mountains (Southern Carpathians, Romania). Quaternary International 415:230-240.

Pretzsch H, Dursky J (2002). Growth reaction of Norway spruce (Picea abies (L.) Karst.) and European beech (Fagus sylvatica L.) to possible climatic changes in Germany. A sensitivity study. Forstwissenschaftliches Centralblatt 121:145-154.

Rolland C, Michalet R, Desplanque C, Petetin A, Aimé S (1999). Ecological requirements of Abies alba in the French Alps derived from dendro-ecological analysis. Journal of Vegetation Science 10(3):297-306.

Rosenvald K, Tullus A, Ostonen I, Uri V, Kupper P, Aosaar J, ... Rohula G (2014). The effect of elevated air humidity on young silver birch and hybrid aspen biomass allocation and accumulation-Acclimation mechanisms and capacity. Forest ecology and management 330:252-260.

Schickhoff U, Bobrowski M, Böhner J, Bürzle B, Chaudhary RP, Gerlitz L, ... Wedegärtner R (2015). Do Himalayan treelines respond to recent climate change? An evaluation of sensitivity indicators. Earth System Dynamics 6:245-265.

Sharma RP, Brunner A, Eid T (2012). Site index prediction from site and climate variables for Norway spruce and Scots pine in Norway. Scandinavian Journal of Forest Research 27(7):619-636.

Spârchez G, Târziu DR, Dincă L (2011). Pedologie [Pedology].Editura Lux Libris, Braşov.

Târziu DR, Spârchez G, Dincă L (2004). Pedologie cu elemente de Geologie [Pedology with elements of Geology]. Editura Silvodel, Braşov.

Theurillat JP, Guisan A (2001). Potential impact of climate change on vegetation in the European Alps: a review. Climatic Change 50(1-2):77-109.

Toromani E, Sanxhaku M, Pasho E (2011). Growth responses to climate and drought in silver fir (Abies alba) along an altitudinal gradient in southern Kosovo. Canadian Journal of Forest Research 41(9):1795-1807.

Vespremenau-Stroe A, Urdea P, Popescu R, Vasile M (2012). Rock Glacier Activity in the Retezat Mountains, Southern Carpathians, Romania. Permafrost and Periglacial Processes 23(3):127-137.

Voiculescu M (2008). Snow avalanche hazards in the Făgăraș massif (Southern Carpathians): Romanian Carpathians Management and perspectives. Natural Hazards 51(3):459-475.

Way DA, Oren R (2010). Differential responses to changes in growth temperature between trees from different functional groups and biomes: a review and synthesis of data. Tree Physiology 30(6):669-688.

Weih M, Karlsson PS (2001). Growth response of Mountain birch to air and soil temperature: is increasing leaf-nitrogen content an acclimation to lower air temperature? New Phytologist 150(1):147-155.

Williams DW, Liebhold AM (2000). Spatial synchrony of spruce budworm outbreaks in eastern North America. Ecology 81(10):2753-2766.

Wiser SK, Allen RB, Platt KH (1997). Mountain beech forest succession after a fire at Mount Thomas Forest, Canterbury, New Zealand. New Zealand Journal of Botany 35(4):505-515.

***Forest management plans of the forest districts: Nehoiașu (1999), Măneciu (1999), Campina (2002), Azuga (1999), Sinaia (2002), Pietroșița (2005), Rucăr (1996), Câmpulung (2006), Aninoasa (2005), Domnesti (2004), 
Mușătești (1994), Vidraru (2005), Cornet (1993), Suici (2008), Brezoi (1991), Voineasa (2003), Latorița (1994), Bumbești (2002), Polovragi (2001), Lupeni (2000), Petroșani (2001), Runcu (2000), Novaci (2002), Întorsura Buzăului (1982), Teliu (1993), Brasov (1993), Săcele (1993), Râșnov (1993), Zărnești (1993), Șercaia (1986), Făgăraș (1985), Voila (1985), Arpaș (1986), Avrig (2005), Tălmaciu (1980), Valea Sadului (1982), Valea Cibinului (1982), Cugir (1993), Bistra (1999), Orăștie (1993), Grădiște (2004), Petrila (2000), Baru (1996), Pui (2005), Retezat (1996).
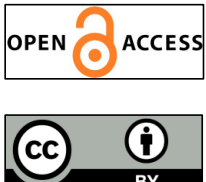

The journal offers free, immediate, and unrestricted access to peer-reviewed research and scholarly work. Users are allowed to read, download, copy, distribute, print, search, or link to the full texts of the articles, or use them for any other lawful purpose, without asking prior permission from the publisher or the author.

License - Articles published in Notulae Botanicae Horti Agrobotanici Cluj-Napoca are Open-Access, distributed under the terms and conditions of the Creative Commons Attribution (CC BY 4.0) License.

(c) Articles by the authors; UASVM, Cluj-Napoca, Romania. The journal allows the author(s) to hold the copyright/to retain publishing rights without restriction. 